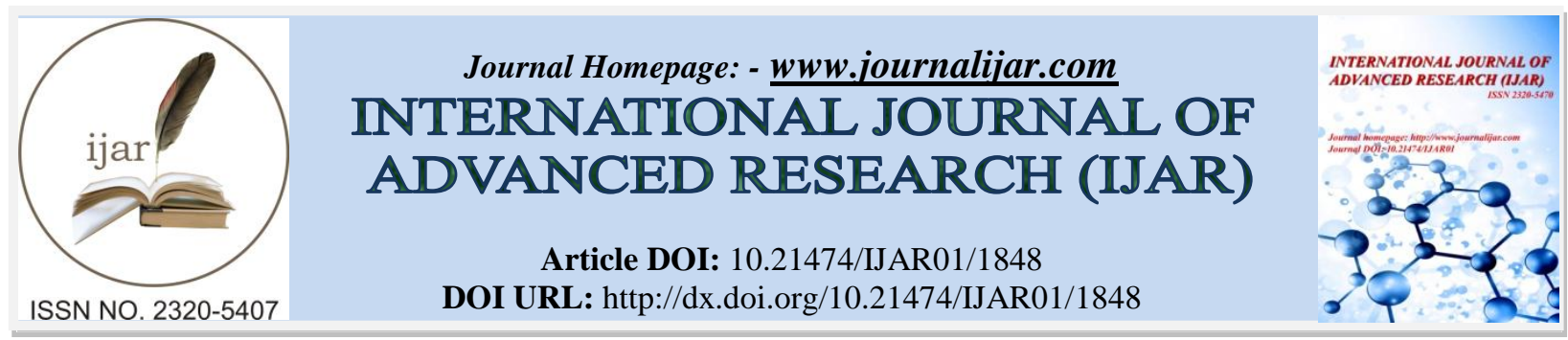

RESEARCH ARTICLE

\title{
LOCATIVENESS AND WAYS OF ITS EXPRESSION IN THE ENGLISH AND UZBEK LANGUAGES
}

\section{Sulaymanova Nilufar Jabborovna.}

Senior teacher, senior scientific researcher of Samarkand State Institute of Foreign Languages (SamSIFL), Samarkand city, Uzbekistan.

\section{Manuscript Info}

Manuscript History

Received: 12 August 2016

Final Accepted: 14 September 2016

Published: October 2016

Key words:-

category of locativeness, locative, predicativeness, preposition, adverbial modifier of place, substantional, transformation, syntaxeme, lexeme, adessive, alative, connotative, facultative, space, language system, element, structure, location, object, suffix.

\section{Abstract}

The present article investigates the category of locativeness in the English language and demonstrates all models of its expression in English sentences. The author enumerates all types of adverbial modifier of place and completely enlightens the problem of expression of locativeness and its role in the sentence structure. Moreover, the article investigates ways of expression of adverbial variants of locative syntaxemes in Uzbek as well as in English basing on comparative aspect. There is detailed information of formulas of adverbial phrases denoting location in English and Uzbek sentences. Theoretical part of the article is proved by examples.

Copy Right, IJAR, 2016,. All rights reserved.

\section{Materials and methods:-}

The actuality of the theme of investigation is obvious in new approach to the problem of expression of locativeness and its function in literary texts. This problem is interesting in modern linguistics and wasn't totally solved though attracted attention of a number of linguists. The category of locativeness is investigated from the structural view of a sentence, where the locativeness is met. In our work we investigated components which express the category of locativeness and models of sentence structures where this category is used. This article is based on investigation of only one variant of so called adverbial modifier of place which is analyzed on the ground of linguistic methods. The method of syntactical analysis is worked out by A.M. Mukhin ${ }^{1}$. This method is based on determination of syntactical connection between syntactical units in the structure of sentences and revealing different syntactical signs and also defining semantic signs of syntactical units. Traditionally syntactical analysis of the sentence structure is based on division of sentences into primary and secondary parts. But, this approach to syntactical analysis of the sentence is limited by formal sides of syntactical units.

\section{Results and Discussion:-}

It is known that adverbial modifier is secondary part of speech which denotes various peculiarities of action: aim, reason, condition, degree, time and place. ${ }^{2}$ The term "locative" means the location of a person or an object. "Adessive" as a new linguistic term means "categorical form of case, indicating the location, belonging, instrument of $\mathrm{n}$ action". In modern linguistic some grammarians called it simply "locative" or "private locative". But this term is not in frequent

\footnotetext{
${ }^{1}$ Mukhin A. M. Functional syntax. Functional lexicology. Functional morphology. - Saint-Petersburg, 2007. - 198 p.
}

Corresponding Author:- Sulaymanova Nilufar Jabborovna.

Address:- Senior teacher, senior scientific researcher of Samarkand State Institute of Foreign Languages (SamSIFL), Samarkand city,Uzbekistan. 
use by linguists. This term is not totally differed from locative ablative, locative translative (linguistic term), locative allative, locative possessive and so on. That's why it would be better use locative adessive as it shows full location human-beings or objects. Syntactical units, expressing locative adessive components can be defined in the position of dependent componential relations with core components on the base of subordinate connection. So in this article we tried to point two main problems:

1. Ways of expressing locative adessive elements;

2. Their variants which can be connotative, selective and adverbial in English and Uzbek languages. The ways of expressing locative adessive elements in English can be expressed with the help of various types of prepositions and nouns, denoting places and locations.

Linguist Sweet H. made out the following classification of adverbial modifier: adverbial modifier of place, adverbial modifier of time, adverbial modifier of reason, adverbial modifier of consequence, adverbial modifier of way of action $^{3}$.

We can give different examples of adverbial modifier:

1. I live in Moscow.

2. I go to Moscow.

3. I came from Moscow.

4. I came to Moscow from London.

5. I went along the streets of Moscow.

In the sentences above we can meet different verbs in the function of participle live, go, came, went which are used with adverbial modifiers of place in Moscow, to Moscow, from Moscow, to Moscow from London, along the streets of Moscow, i.e. we deal with category of locativeness which is expressed with the help of locative prepositions and names of cities. If we analyze these sentences deeper, we can find out that in the first sentence I live in Moscow locativeness and adhesiveness is expressed (the place is concretely pointed).

In the second sentence I go to Moscow - locativeness and allativeness is expressed (the direction towards the object of place is pointed).

In the third sentence I came from Moscow - locativeness and allativeness is expressed (the direction from the object of place is pointed).

In the forth sentence I came to Moscow from London - locativeness and translativeness is expressed (two directions: towards the object of place and from another object of place is pointed).

The last sentence I went along the streets of Moscow denotes pure locativeness (points the object of place without any directions).

The English language is rich in verbs denoting the category of locativeness: enter, approach, cross, lie, stand, sit, live, be, abide, dwell, inhabbit, lodge, nestle, reside, roast, sojourn, stay, walk, amble, dodder, follow, hobble, limp, merit, pace, paddle, perambulate, plod, peal, ramble, reel, roam, rove, saunter, sough, shamble, shuffle, sidle, stagger, stack, stride, stroll, stream, stump, swagger, swing, toddle, totter, tramp, tread, trip, trot, trudge, wiggle and others.

Some linguists make out locative relations denoting subject, action, event, sign and other peculiarities ${ }^{4}$ :

1. Subject of locativeness: in London - near London;

2. The degree of measuring the subject of locativeness: in London - through London;

3. Locative relations: in London - to London.

Adverbial variants of locative adessive syntaxemes in the structure of the sentences can be connected with the verb and point out the location of an action or an object, its state and space. We must mention that some prepositions in English may be changed into adverbial elements. So, above pointed adverbs can be used as notional meaning and

\footnotetext{
${ }^{3}$ Sweet H. A New English Grammar, Logical and Historical. - Part I. - Oxford: Clarendon press, 2004. - P.187.

${ }^{4}$ Zandvoort R.W. A Handbook of English Grammar. Groningen, 1998. - P. 221.
} 
express locative adessive, locative alative, locative ablative syntaxemes. According to the results of analysis of English and Uzbek sentences with locative adessive syntaxemes we came to the following conclusions:

Syntactic elements expressing locative adessive syntaxemes are realized in the non-central depended component in the structure of the sentences and they are related with other components on the base of subordinative connection.

Locative adessive syntaxeme expresses the location of a person or an object, and the action takes place in that space. On the base of subordinative syntactical connection, locative adessive syntaxemes can be related with object, possessive, temporal, qualitative, actionable, substantial object, actionable object, existential, actionable directive, locative alative, stative, modal stative, substantional identificator syntaxemes.

Locative adessive syntaxemes are investigated on the categorical syntactic-semantic sign-substantiality. On the basis of substantiality we examined only one type of locative syntaxemes such as locative adessive syntaxemes in the structure of English and Uzbek sentences comparatively. As the results of investigation of locative adessive syntaxemes we revealed their variants. They may be connotative, facultative and adverbial variants. Connotative variations of locative adessive adessive syntaxemes may be formed by means of combination of various prepositions with nouns expressing location; they can't change one version with another one. But their meaning is the same in English.

Connotative variants of locative adessive syntaxemes are formed by means of inside $+S$, in/on the opposite of $+S$, in $+S$, round or around $+S$ and etc. Those prepositional $+S$ combinations are variants of locative adessive syntaxemes. While determining locative adessive syntaxemes by means of these prepositional noun combinations we take into consideration their meaning which illuminates oppositional relationship of invariants. As we pointed above those prepositional noun combinations are connotative variants which are not changed with each other as facultative variants. That can't influence on the lexical meaning of the variants. That can't influence on the lexical meaning of the noun either. Now, we'll demonstrate connotative variants of locative adessive syntaxemes separately.

Variant inside $+\mathrm{S}$ expresses that the action takes place inside of the space or an object:

We just managed to keep inside the boot.

Variant on the opposite of $+S$ indicates an object or a person, situated on the opposite of the space:

The grocer's boy passed on the opposite of the street.

Variant in $+\mathrm{S}$ expresses the situation of an object or a person in definite space or reach there. As we know the preposition "in" is polysemantic, and it expresses the location of an object or a person where a person lives:

They had spent in the woods of Skene.

Variant around or round $+\mathrm{S}$ expresses the action which takes place around the object or a person:

They brought the cars around the villa.

Variant outside $+\mathrm{S}$ or out of $+\mathrm{S}$ expresses that the person or an object disposed outside of a space:

The boys have stopped outside Udina.

Variant over $+S$ or above $+S$, which indicate the action as a person takes place above the space:

Queen Elisabeth passed on the right bank just half a mile above Merlav Bridge.

Variant near $+\mathrm{S}$ indicates a person or an object, situated near the space:

She came near the gates of the city.

Variant under $+\mathrm{S}$ indicates a person or an object, situated under the space:

We stopped under the willows by Kempton Park.

Variant between $+\mathrm{S}$ indicates a person or an object, situated between two spaces:

He had already traced between the altar and the tripod. 
Variant behind $+\mathrm{S}$ indicates a person or an object, situated on the other side of the space:

I've got a cab behind the door.

Variant in the middle of $+\mathrm{S}$ indicates an action, which takes place in the centre of a space:

She stood in the middle of the room.

Variant along $+\mathrm{S}$ indicates an action, which takes place on the space:

They walked along the passage.

Above pointed facts prove that all the lexemes expressing locative syntaxemes are very complicated as the lexemes expressing location are general and their individual meaning is independent. But substantional lexemes expressing adessive syntaxemes may consist of different semantic groups of nouns. So, in English sentences S-subject comes after any preposition denoting location but in Uzbek subject appears in front of adverbial elements of location. As the resume of the article we can demonstrate the following:

We revealed connotative, facultative and adverbial variants of locative adessive syntaxemes in English and Uzbek languages.

\section{Connotative variants:}

\section{In English}

Inside $+S$; on the opposite of $+S$; in $+S$; around or round $+S$; outside $+S$ or out of $+S$; over $+S$; near $+S$; under + $\mathrm{S}$; between $+\mathrm{S}$; in the middle of $+\mathrm{S}$; along $+\mathrm{S}$.

\section{In Uzbek}

$\mathrm{S}+$ ortida; $\mathrm{S}+$ adogida $; \mathrm{S}+$ urtasida $; \mathrm{S}+$ tepasida $; \mathrm{S}+$ ustida $; \mathrm{S}+$ burchagida $; \mathrm{S}+$ ungida $; \mathrm{S}+$ qoshida $; \mathrm{S}+$ atrofida; $\mathrm{S}+$ yuqorida; $\mathrm{S}+$ labida; $\mathrm{S}+$ orasida, ostida.

\section{Facultative variants:-}

- $\quad \mathrm{On}+\mathrm{S}=$ over $+\mathrm{S}=$ across $+\mathrm{S}$

In English:

- $\quad$ Under $+\mathrm{S}=$ at the bottom of $+\mathrm{S}$;

- $\quad$ Behind $+\mathrm{S}=$ on the other side of $+\mathrm{S}=$ on $+\mathrm{S}$ 'back;

- $\quad B y+S=$ near $+S=$ in front of $+S$;

- $\quad$ Against $+S=$ in/on the opposite $+S$;

- $\quad$ In $+\mathrm{S}=$ inside $+\mathrm{S}$.

- $\quad \mathrm{S}+$ ning oldida $=\mathrm{S}+$ ning yonida;

- $\quad \mathrm{S}+$ ostida $=\mathrm{S}+$ tagida;

- $\mathrm{S}+$ atrofida $=\mathrm{S}+$ tevaragida $=\mathrm{S}+$ tarafda $=\mathrm{S}+$ tomonda .

Adverbial variants of locative adessive syntaxemes can be expressed by pronouns or adverbs indicating the space. This syntaxemes may be formed by prepositionless adverbs in English and in Uzbek - adverbs with the suffix - da expressing the space.

In the English sentences the category of locativeness can be expressed in various sentence structures:

1. In the function of adverbial modifier of central predicative: They were fighting in the Carpathiens.

2. In the function of adverbial modifier of none-central predicative: I had met two gunners in Milan.

3. In the function of adverbial modifier of pure predicative: The people at the Manor House didn't wait to hear us talk.

If we analyze the sentence They were fighting in the Carpathiens we can conclude that between component they and were fighting there exists predicative connection, where they is central predicative 1, were fighting is central predicative 2, in the Carpathiens - adverbial modifier of place expressing category of locativeness.

It is easy to notice that the category of locativeness in the English language is expressed by locative preposition + subject: We sat in the hay. But it should be pointed that this model does not always express only location or place: He was sent in ten minutes. 
In these sentences in the hay and in ten minutes are syntactic units, in the first sentence in the hay expresses substantional locativeness, in the second sentence in ten minutes denotes substantionality and temporality.

Substantional and temporal components in these sentences can be replaced by adverbial elements:

1. We sat in the hay $\rightarrow$ we sat here/there

2. He was sent in ten minutes $\rightarrow$ he was sent then.

We can ask questions to above pointed sentences in order to prove that there were used substantional and temporal components:

1. We sat in the hay $\rightarrow$ where did we sit?

2. He was sent in ten minutes $\rightarrow$ when was he sent?

We investigated cases when locativeness was expressed by qualificativeness. This was very interesting research which proved that there exist cases when qualificative category is replaced by locative category and denotes place:

1. You have a beach cottage.

2. ... the boring sameness of army life was pleasant.

In these examples syntactic units beach, army which are designed for expressing qualificative category change their role in the sentences and obtain locative category:

1. ... you have a beach cottage $\rightarrow$ you have a cottage on the beach.

2. ... the boring sameness of army life was pleasant $\rightarrow$ the boring sameness of life in the army was pleasant.

Here a phenomenon of transformation took place, what can be proved by replacing syntactical units on the beach, in the army by adverbials there/here:

1. ... you have a beach cottage $\rightarrow$ you have a cottage here/there.

2. ... the boring sameness of army life was pleasant $\rightarrow$ the boring sameness of life here/there was pleasant.

The category of locativeness can be expressed by various semas in the English language:

1. Objective sema: He makes a job at the pand.

2. Possessive sema: She had worked industriously at Colarossi's Academy.

3. Temporal sema: He had already spent morning at the Hotel Dieu.

4. Qualitative substantional sema: But at the operating table Arthur was different.

5. Actional sema: Who had just stopped at the inn, came to the door of the room.

6. Substantional objective sema: The hotels at ship lake and Henley would be crammed.

7. Actional objective sema: Harris wanted to get out at Hampton Church.

8. Existentional sema: I don't believe he is at the bank.

9. Sotiative sema: He invited her to lunch with him at a restaurant.

10. Actional sema: She was seated at the royal table.

11. Locative allative sema: He had come to the shore at dawn.

12. Stative sema: You shall live at the palace.

13. Modal stative sema: They were to sleep in the same room.

14. Identificative sema: They are monuments in Bisham Church.

In English and Uzbek language systems adverbial variants of locative adessive syntaxemes can be expressed by means of pronouns or adverbs denoting space: here - bu yerda, shu yerda; there - usha yerda, u joyda; near yaqinida, yonida; behind - orqasida; within - ichida; outside - tashqarida; upstairs - yuqorida; inside - ichida, ichki tomonida; backward - orqa tomonida; around - atrofida; past - yonida, yaqinida; where - qaerda; above - ustida, tepasida; somewhere - bir joyda, alla qaerda; nowhere - hech qaerda; everywhere - hamma joyda; anywhere - biror joyda; below - ostida, pastida; under - ostida, tagida; downstairs - pastida, past qavatda; back - orqasida. 


\section{Conclusion:-}

1. In Uzbek language locative adessive elements are formed by means of adding suffix - da to the noun. However, some grammarians point out that locative adessive elements express the action where takes place an event or located a person or an object.

2. In English language system locative adessive elements can be expressed with the help of above given propositions in, on, at, over, under, etc.+ Noun in Common case.

3. Comparing both language systems in the usage of locative adessive elements we come to conclusion that in English locative adessive elements are expressed by a wider number of prepositions while in Uzbek it is expressed either by some suffixes or adverbial of place.

4. Adverbial variants of locative adessive syntaxemes in English are expressed in two ways: 1. by pronouns, 2. by prepositions, but in Uzbek - by means of adverbs, expressing location. 